Proc. Estonian Acad. Sci. Biol. Ecol., 2003, 52, 1, 73-78

\title{
Effect of green manuring on Globodera rostochiensis and Pratylenchus spp. (Nematoda)
}

\author{
Zlatka Trifonova \\ Plant Protection Institute, 2230 Kostinbrod, Bulgaria; protection@infotel.bg \\ Received 23 January 2002, in revised form 19 June 2002

\begin{abstract}
Concomitant effect of Globodera rostochiensis and Pratylenchus spp. on potato was investigated under glasshouse conditions. G. rostochiensis alone or with Pratylenchus spp. reduced significantly the weight and number of size $3(>100 \mathrm{~g})$ tubers. Experiments with various green manure crops showed that growing Brassica nigra L. and Tagetes patula L. prior to potato resulted in a decline of G. rostochiensis and Pratylenchus spp. population densities and a tuber yield increase compared to control. Hordeum vulgare L. increased the density of Pratylenchus spp. in soil.
\end{abstract}

Key words: Nematoda, population density, intercropping, green manure.

\section{INTRODUCTION}

Nematodes are one of the major limiting factors for potato production in Bulgaria. Predominant nematode pests identified from the rhizosphere of potato are cyst nematodes (Globodera spp.), root lesion nematodes (Pratylenchus spp.), and stubby root nematodes (Trichodorus spp. and Paratrichodorus spp.) (Brown et al., 1980; Trifonova, 1998). Globodera rostochiensis and Pratylenchus neglectus or P. penetrans reduce the quality and yield of potato (Bernard \& Laughlin, 1976; Stoyanov \& Assenova, 1987; Olthof, 1990; Trifonova, 1995).

Nematode control for potato includes a combination of chemical and cultural practices to suppress nematode populations. Green manuring has been reported to be effective for the control of plant parasitic nematodes in some countries (Mojtahedi et al., 1991; Mahmood \& Siddiqui, 1993; Siddiqui \& Mahmood, 1993). Several plants have been found to contain nematotoxic principles and have been used to control plant nematodes (Sangwan et al., 1985; Pandely et al., 2001). Mustard (Brassica juncea), neem (Azadirachta indica), and castor-oil plant (Ricinus communis) have been reported to reduce nematode population densities 
in potato (Akhtar \& Alam, 1991). Incorporation of organic matter into the soil and intercropping are aimed at increasing crop production. Both practices have been used by farmers for many years. However, little is known about the use and effectiveness of green manure crops for controlling G. rostochiensis and Pratylenchus spp. in potato growing areas.

The objectives of this study were to evaluate the pathogenicity of Pratylenchus spp. alone and in combination with G. rostochiensis on potato and determine the efficacy of various green manure crops on potato yield in the presence of G. rostochiensis and Pratylenchus spp.

\section{MATERIALS AND METHODS}

The experiments were conducted in a glasshouse. Pots $(5 \mathrm{~L})$ were filled with sterile soil. The population of G. rostochiensis was obtained from a field. Cysts were extracted by the wet-sieve decantation technique. Second-stage juveniles $\left(\mathrm{L}_{2}\right)$ were obtained by exposing soaked cysts to potato root diffusate. The Pratylenchus population was collected from an infested barley field. Specimens for the inoculum were extracted from the soil by Cobb's sieve technique (Shepherd, 1970).

Single potato tubers (Solanum tuberosum cv. Focal) were planted in each pot. After a week, suspension of $10000 \mathrm{~L}_{2}$ G. rostochiensis or 10000 Pratylenchus spp. or both was added to each pot. Uninoculated pots were used as controls. Regular cultural practices were followed. Three months after planting the tubers were harvested, weighed, and the yield data were recorded. Each treatment was replicated five times.

In a second experiment $200 \mathrm{~g}$ of freshly chopped leaves and roots of barley (Hordeum vulgare L.), mustard (Brassica nigra L.), pea (Pisum arvense L.), or marigold (Tagetes patula $\mathrm{L}$.) was added to the pots as green manure. The control pots received no green manure. The pots were watered daily. Single potato tubers were planted in the pots and nematodes were added at a rate of $10000 \mathrm{~L}_{2}$ G. rostochiensis and 10000 Pratylenchus spp. alone or combined per pot. All the treatments were replicated five times. The crops were harvested after three months. Nematodes were recovered from the soil samples by Cobb's method and wet-sieve decantation technique. The potato tubers were categorized by size (size $1=<50 \mathrm{~g}$, small; size $2=50-100 \mathrm{~g}$, medium-sized; size $3=>100 \mathrm{~g}$, large). Data were compared by analysis of variance and Duncan's multiple range test.

\section{RESULTS AND DISCUSSION}

Treatment with G. rostochiensis alone or concomitantly with Pratylenchus spp. reduced significantly the weight and number of size 3 tubers and suppressed the potato yield as compared to control (Table 1). Also Pratylenchus spp. alone 
Table 1. Effect of Globodera rostochiensis and Pratylenchus spp. on mean potato weight and size distribution

\begin{tabular}{l|c|c|c|c}
\hline \multirow{2}{*}{ Nematode } & Tuber weight, & \multicolumn{3}{c}{ Mean number per pot } \\
\cline { 4 - 5 } & $\mathrm{g}$ & $<50 \mathrm{~g}$ & $50-100 \mathrm{~g}$ & $>100 \mathrm{~g}$ \\
\hline \multirow{2}{*}{ Pratylenchus spp. } & $517.8 \mathrm{~b}$ & $3.6 \mathrm{c}$ & $3.2 \mathrm{~d}$ & $0.96 \mathrm{ab}$ \\
G. rostochiensis & $298.8 \mathrm{a}$ & $1.8 \mathrm{a}$ & $2.8 \mathrm{c}$ & $1.20 \mathrm{~b}$ \\
Pratylenchus spp. + G. rostochiensis & $304.8 \mathrm{a}$ & $2.0 \mathrm{ab}$ & $1.8 \mathrm{a}$ & $0.80 \mathrm{a}$ \\
Control & $912.8 \mathrm{c}$ & $2.2 \mathrm{~b}$ & $2.2 \mathrm{~b}$ & $7.40 \mathrm{c}$ \\
& & & & \\
$\quad F$ & 96.02 & 8.89 & 8.59 & 249 \\
$\quad$ SE & 41.58 & 0.387 & 0.299 & 0.288 \\
& & & &
\end{tabular}

Means in columns followed by the same letters are not significantly different according to Duncan's multiple range test (for $P=0.05$ ).

suppressed size 3 tubers as compared to uninoculated control. Olthof (1990) reported that Pratylenchus neglectus suppresses the total number of tubers by $25 \%$. Kimpinski \& McRae (1988) found a linear relationship between the number of root lesion nematodes at planting and tuber yield increases after aldicarb treatment.

In our study green manure treatments influenced significantly tuber weight and size distribution (Table 2). The total yield of tubers from all green manure treatments was significantly higher than control. The yields from the mustard, marigold, and pea treatments were significantly higher than from barley treatments. The number of size 1 and 2 tubers was the smallest from the marigold treatments.

Table 2. Efficacy of green manures on potato tuber yields and size distribution in the presence of Globodera rostochiensis and Pratylenchus spp.

\begin{tabular}{l|c|c|c|c}
\hline \multirow{2}{*}{ Treatment } & Tuber weight, & \multicolumn{3}{c}{ Number per pot } \\
\cline { 3 - 5 } & $\mathrm{g}$ & $<50 \mathrm{~g}$ & $50-100 \mathrm{~g}$ & $>100 \mathrm{~g}$ \\
\hline \multirow{2}{*}{ Mustard } & $746.6 \mathrm{c}$ & $3.2 \mathrm{~d}$ & $2.0 \mathrm{~b}$ & $6.6 \mathrm{e}$ \\
Marigold & $740.0 \mathrm{c}$ & $0.8 \mathrm{~b}$ & $1.8 \mathrm{ab}$ & $5.4 \mathrm{~d}$ \\
Barley & $718.2 \mathrm{~b}$ & $1.6 \mathrm{c}$ & $2.8 \mathrm{c}$ & $2.8 \mathrm{~b}$ \\
Pea & $742.0 \mathrm{c}$ & $0.0 \mathrm{a}$ & $3.4 \mathrm{~d}$ & $4.4 \mathrm{c}$ \\
Control & $400.2 \mathrm{a}$ & $3.8 \mathrm{e}$ & $1.6 \mathrm{a}$ & $0.8 \mathrm{a}$ \\
\multicolumn{1}{c}{$F$} & & & & \\
$\quad$ SE & 133 & 38.1 & 9.23 & 44.7 \\
& 18.459 & 0.336 & 0.352 & 0.479 \\
\end{tabular}

Means in columns followed by the same letters are not significantly different according to Duncan's multiple range test (for $P=0.05$ ). 
Significantly more size 3 tubers (the largest category) than control were produced in all green manure treatments. These results clearly indicate that higher potato yields with more large tubers may be obtained by using green manures as a cultural practice.

Among all green manure crops studied the largest populations of Pratylenchus spp. in the soil were recorded in the case of barley (Table 3). Marigold treatment reduced significantly soil populations of Pratylenchus spp. G. rostochiensis populations were smaller than control in the soil from all green manure treatments. The highest decrease was observed in pots treated with mustard. However, marigold, barley, and pea also supported significantly lower populations than control. The largest reduction in nematode multiplication for G. rostochiensis (79.7\%) occurred in the mustard and for Pratylenchus spp. in the marigold (43.7\%) treatment.

The finding that green manuring with mustard is more effective against G. rostochiensis than marigold, pea, or barley treatments is in agreement with the results of Akhtar \& Alam (1991), who reported reduction in nematode numbers due to mustard (Br. juncea) grown along with potato.

The nematicidal or nematostatic effect of marigold is associated with its high content of $\alpha$-terthienyl (Uhlenbroek \& Bijloo, 1958). These results are in agreement with those of Sasanelli \& D'Addabbo $(1992,1993)$ and Hachney \& Dickerson (1975), who reported nematotoxic properties of Tagetes spp.

It would be useful to ascertain whether the cultivation of these plants for short periods or their application as green manure could be beneficial for the control of nematodes in the field.

Table 3. Efficacy of various green manures in controlling the population of Globodera rostochiensis and Pratylenchus spp.

\begin{tabular}{l|c|c|c|c}
\hline \multirow{2}{*}{ Treatment } & \multicolumn{2}{|c|}{ G. rostochiensis } & \multicolumn{2}{c}{ Pratylenchus spp. } \\
\cline { 2 - 5 } & $\begin{array}{c}\text { No. in } 200 \mathrm{~g} \\
\text { soil }\end{array}$ & $\begin{array}{c}\text { Reduction in } \\
\text { comparison with } \\
\text { control, \% }\end{array}$ & $\begin{array}{c}\text { No. in 200 g } \\
\text { soil }\end{array}$ & $\begin{array}{c}\text { Reduction in } \\
\text { comparison with } \\
\text { control, \% }\end{array}$ \\
\hline Mustard & $52.2 \mathrm{a}$ & 79.7 & $159.8 \mathrm{c}$ & 4.3 \\
Marigold & $155.6 \mathrm{~b}$ & 39.5 & $93.6 \mathrm{a}$ & 43.7 \\
Barley & $165.0 \mathrm{~b}$ & 35.6 & $316.8 \mathrm{~d}$ & -90 \\
Pea & $162.4 \mathrm{~b}$ & 36.8 & $142.0 \mathrm{~b}$ & 14.5 \\
Control & $256.4 \mathrm{c}$ & - & $166.8 \mathrm{c}$ & - \\
\multicolumn{1}{c}{$F$} & & & & \\
\multicolumn{1}{c}{$\mathrm{SE}$} & 90 & & 189.9 &
\end{tabular}

Means in columns followed by the same letters are not significantly different according to Duncan's multiple range test (for $P=0.05$ ). 


\section{REFERENCES}

Akhtar, M. \& Alam, M. M. 1991. Integrated control of plant-parasitic nematodes on potato with organic amendments, Nematicide and mixed cropping with mustard. Nematol. Mediter., 19, $169-171$.

Bernard, E. C. \& Laughlin, C. W. 1976. Relative susceptibility of selected cultivars of potatoes to Pratylenchus penetrans. J. Nematol., 8, 239-242.

Brown, M. J., Riedel, R. M. \& Rowe, R. C. 1980. Species of Pratylenchus associated with Solanum tuberosum cv. Superior in Ohio. J. Nematol., 12, 189-192.

Hachney, R. W. \& Dickerson, O. J. 1975. Marigold, castor, bean, and chrysanthemum as controls of Meloidogyne incognita and Pratylenchus alleni. J. Nematol., 7, 84-90.

Kimpinski, Y. \& McRae, K. B. 1988. Relationship of yield and Pratylenchus spp. population densities in Superior and Russet Burbank potato. Ann. Appl. Nematol., 2, 34-37.

Mahmood, I. \& Siddiqui, Z. A. 1993. Integrated management of Rotylenchulus reniformis by green manuring and Paecilomyces lilacinus. Nematol. Mediter., 21, 285-287.

Mojtahedi, H., Santo, G. S., Hang, A. N. \& Wilson, J. H. 1991. Suppression of root-knot nematode populations with selected rapeseed cultivars as green manure. J. Nematol., 23, 170-174.

Olthof, T. H. A. 1990. Reproduction and parasitism of Pratylenchus neglectus on potato. J. Nematol., 22, 303-308.

Pandely, R., Pant, N., Jain, D. C. \& Karla, A. 2001. Nematicidal plant extracts as potent source of nematicidal activities. Nematol. Mediter., 29, 19-21.

Sangwan, N. K., Verma, K. K., Verma, B. S., Mauk, M. S. \& Dhindsa, K. S. 1985. Nematicidal activity of esectial oil of cymbopogon grasses. Nematologica, 31, 93-99.

Sasanelli, N. \& D'Addabbo, T. 1992. The effect of Cineraria maritima, Ruta graveolens and Tagetes erecta extracts on the hatching of Heterodera schachtii. Nematol. Mediter., 20, 49-51.

Sasanelli, N. \& D'Addabbo, T. 1993. Effect of Cineraria maritima, Ruta graveolens and Tagetes erecta leaf and root extracts on Italian populations of Meloidogyne species. Nematol. Mediter., 21, 21-25.

Shepherd, A. M. 1970. Laboratory Methods for Work with Plant and Soil Nematodes. 5th ed. (Southey, J. F., ed.). Her Majesty's Stationery Office.

Siddiqui, Z. A. \& Mahmood, I. 1993. Integrated control of root-rot disease complex of chickpea by fungal filtrates and green manuring. Nematol. Mediter., 21, 161-164.

Stoyanov, D. \& Assenova, N. 1987. Possibilities for control of potato nematode G. rostochiensis Woll. 1923 with oxamyl. In Fifth National Conference of Parasitology, 1-3 October, Varna, p. 111.

Trifonova, Z. 1995. Use of some systemic nematocides for controlling potato cyst nematode G. rostochiensis. Woll. 1923. Bulg. J. Agric. Sci., 1, 433-438.

Trifonova, Z. 1998. Potato phytonematode fauna in Bulgaria. Bulg. J. Agric. Sci., 4, 293-297.

Uhlenbroek, J. H. \& Bijloo, J. D. 1958. Investigations on nematicides. Isolation and structure of a nematicidal principle occurring in Tagetes roots. Rec. Trav. chim. Pays-Bas., 77, 1004-1009.

\section{Haljasväetise toime koldsele kartuli-kiduussile (Globodera rostochiensis) ja niiduingerjatele (Pratylenchus spp.) (Nematoda)}

\section{Zlatka Trifonova}

Kasvuhoone vegetatsioonikatsetes selgitati koldse kartuli-kiduussi ja niiduingerjate koosmõju kartulile (Solanum tuberosum cv. Focal). Kiduussid eraldi ja 
koos niiduingerjatega vähendasid suurte (üle $100 \mathrm{~g}$ ) mugulate saaki. Haljasväetisena kasutatud must kapsasrohi (must sinep Brassica nigra L.) ja peiulill (Tagetes patula L.) vähendasid tunduvalt mõlema nematoodi arvukust. Sellega kaasnes saagikuse tõus. Koldse kartuli-kiduussi arvukus vähenes ka odra toimel, kuid niiduingerjate asurkonna tihedus mullas suurenes odra toimel oluliselt. 